Article

\title{
Trauma, Postmemory, and Empathy: The Migrant Crisis and the German Past in Jenny Erpenbeck's Gehen, ging, gegangen [Go, Went, Gone]
}

\section{Brangwen Stone}

Department of International Studies, Macquarie University, Sydney, NSW 2109, Australia; brangwen.stone@mq.edu.au

Academic Editor: Gail Finney

Received: 25 September 2017; Accepted: 7 November 2017; Published: 11 November 2017

\begin{abstract}
The novel Gehen, ging, gegangen [Go, Went, Gone] by the celebrated German writer Jenny Erpenbeck was published at the height of the European refugee crisis. The novel tells the tale of Richard, a retired Berlin classics professor, who becomes intrigued by the Oranienplatz refugee protest camp. He initially approaches the refugee crisis as a new research project, methodically searching for secondary literature, composing questionnaires and conducting interviews with asylum seekers, but eventually he begins to develop friendships with some of them. Throughout the novel, Richard, who fled from the approaching Red Army with his mother as a baby and then lived in the German Democratic Republic (GDR) until reunification, notices similarities between the traumatic experiences of the Oranienplatz protesters and the trauma in his personal history, German collective history, and ancient and medieval literature. This article focuses on trauma and empathy in Gehen, ging, gegangen, exploring how the parallels drawn between the varied fates of the asylum seekers and the stories of exile and displacement in the literary canon, and German historical experiences of displacement and loss of home, establish points of empathic connection between Richard and the refugees, and attempt to establish the same between the reader and the refugees.
\end{abstract}

Keywords: trauma; postmemory; empathy; German literature; refugee; Erpenbeck; Gehen, ging, gegangen; Go, Went, Gone

\section{Introduction}

The novel Gehen, ging, gegangen [Go, Went, Gone] by the celebrated German writer Jenny Erpenbeck was published in the late summer of 2015 at the peak of the European refugee crisis, a week before Angela Merkel opened Germany's borders to refugees. It was hailed variously as the Roman der Stunde ['novel of the hour'] (Von Sternburg 2015), Roman der Saison ['novel of the season'] (Magenau 2015), and Roman zur politischen Situation ['novel for the political situation'] (Lühmann 2015) in reviews, although it was based on earlier events. The novel centers on Richard, a widowed Berlin classics professor, who has recently retired. Leading a mundane and somewhat lonely existence, he becomes intrigued by the refugees occupying Oranienplatz (a public square in the central Berlin neighbourhood of Kreuzburg), after first becoming aware of the refugee protests due to a hunger strike on Alexanderplatz. According to a recently published UNHCR report, the number of refugees registered worldwide in 2016 was greater than ever before (UNHCR 2017). Yet, the trauma and anguish experienced by the millions of refugees currently displaced from their homes are not unprecedented. Stories of involuntary displacement have been told since the beginning of time. Narratives of flight and exile are central to a range of canonical texts, including Homer's Odyssey, to which Erpenbeck's narrator Richard refers several times, Virgil's Aeneid, the Bible, the Qu'ran, and the modernist novels written by "exiles and émigrés" (Eagleton 1970). The twentieth century saw millions of people forced 
from their homes as a result of political upheaval on an unprecedented scale, including two world wars, the Cold War, and decolonization. Thus Edward Said declared the twentieth century "the age of the refugee, the displaced person, [and] mass immigration" (Said 2002, p. 159). Equally, the figure of the refugee became one of Giorgio Agamben's key examples to illustrate that "[t]he fundamental categorical pair of Western politics is not that of friend/enemy but that of bare life/political existence, zoé/bios, exclusion/inclusion" (Agamben 1998, p. 8). ${ }^{1}$ Yet, as Aleida Assmann notes, the phenomenon of forced dislocation has not yet been sufficiently integrated into collective European memory:

Die Erfahrung von Flucht, Vertreibung und Migration hat noch keine klare Kontur und Symbolik in der europäischen Erinnerungskultur erhalten. Dafür fehlt vorerst noch ein Narrativ und das liegt wohl nicht zuletzt daran, dass es sich hier um eine im wahrsten Sinne des Wortes 'unendliche Geschichte' handelt, die sich in ganz unterschiedlichen historischen Kontexten wiederholt.

The experience of flight, expulsion and migration has no clear contours or symbolism in European memory culture yet. The narrative necessary for this to be the case does not yet exist, not least because it is a "never-ending story" in the truest sense of the word, which repeats itself in very different historical contexts.' ${ }^{2}$ (Assmann 2016a).

This article will focus on the role of trauma and empathy in Gehen, ging, gegangen, exploring how the parallels drawn between the varied fates of the Oranienplatz asylum seekers and the stories and experiences of exile and displacement in the literary canon, and German history, establish points of empathic connection between Richard and the refugees, and attempt to establish the same between the reader and the refugees.

\section{The Occupation of Oranienplatz}

The occupation of Oranienplatz on which Erpenbeck based Gehen, ging, gegangen began in the autumn of 2012 and lasted for 550 days. The 100-150 protesters, who came from "Sudan, Uganda, Syria, Eritrea, Somalia, Afghanistan and other nations converted [the] square into an urban campsite that served as a loaded space for social and political discussion and negotiation" (Landry 2015, p. 399). The wave of protests that eventually resulted in the protest camp was triggered by the suicide of an Iranian asylum seeker in Würzburg in early 2012, to which protesters reacted with a hunger strike (Wiedemann 2015). By the late summer of 2012, there were tent protests against German refugee policy and the poor conditions in many homes for asylum seekers in most major German cities (Landry 2015, pp. 400-2). In early September, a 28-day march from Würzburg to Berlin followed. On arrival in Berlin, the asylum seekers and their supporters initially set up camp on Pariser Platz next to the Brandenburger Tor, but a move to Oranienplatz was soon negotiated at the invitation of the then mayor of Kreuzberg-Friedrichshain, Franz Schulz of the Green Party (Landry 2015, pp. 402-3). A few months later, as winter began, a number of the refugee activists moved to the nearby abandoned Gerhart-Hauptmann school (Bhimji 2016, p. 9). The occupation of Oranienplatz ended in April 2014, when the protesters were persuaded to move to temporary accommodation with the promise that their applications for asylum would be expedited (Fadaee 2015, p. 735). Some protesters refused to clear the Oranienplatz, and the female Sudanese activist Napuli Langa, whose actions are briefly alluded to by Erpenbeck (Erpenbeck 2015, p. 4), spent five nights in a tree (Wiedemann 2015). A number of protesters continued to occupy part of the Gerhart-Hauptmann school at the time this essay was written (Gehrke 2017). The occupation of Oranienplatz brought the plight of asylum seekers to public attention in Berlin and throughout Germany, and is thought to have been a deciding factor in the lifting of the Residenzpflicht (residence duty), which prevented asylum seekers from leaving the state

1 Imogen Tyler warns that the "theoretical turn to the figure of the refugee or asylum seeker within disciplines such as philosophy and cultural studies risks becoming a means of not hearing asylum seekers" (Tyler 2006, p. 199).

2 All translations in this article are the author's own, unless otherwise noted. 
where they registered, and also in the introduction of a new rule allowing asylum seekers the right to work in Germany after a restricted period (Landry 2015, p. 410). ${ }^{3}$

\section{The Oranienplatz Protesters in Gehen, ging, gegangen}

In Gehen, ging, gegangen, Richard, a widowed, recently-retired professor who shares the narration of the novel with other characters and an omniscient third-person narrator, is at a loss as to how to fill his days. He initially approaches the refugee crisis as a new research project to replace what retirement has taken away. At first he methodically searches for secondary literature, composes questionnaires, and conducts interviews with asylum seekers, but eventually he begins to develop friendships with some of them. Erpenbeck has stated that the novel is based on similar interviews she herself undertook with the Oranienplatz protesters (Bartels 2015). Throughout the novel, Richard, who fled Silesia from the approaching Red Army with his mother as a baby and then lived in the German Democratic Republic (GDR) until reunification, remembers elements of his own life. He notices similarities between the experiences of the asylum seekers and his personal history, but also parallels with German collective history, ranging from World War II to the subsequent flights, expulsions and deprivations; life under surveillance in the GDR, to the fall of the Berlin Wall and life in the reunified Germany. As an emeritus classics professor, he is also reminded of the narratives of exile and displacement in the ancient literary canon, alluding on numerous occasions to Odysseus and the Odyssey, for instance (Erpenbeck 2015, pp. 13, 32-33, 73, 187).

Richard's interest in the Oranienplatz asylum seekers is not triggered until more than a year into the protest, after hearing three pieces of news. First, he hears of a hunger strike on the Alexanderplatz (Erpenbeck 2015, pp. 20,27), and soon after, in short succession, he learns of the sinking of a boat filled with refugees off the island of Lampedusa, and of the Oranienplatz protests (Erpenbeck 2015, p. 33). He starts researching the countries of origin of the refugees who drowned near Lampedusa (Erpenbeck 2015, pp. 33-34). A few days later he visits Oranienplatz and sees "[e]ine Landschaft aus Zelten, Bretterbuden und Planen: weiß, blau und grün" (Erpenbeck 2015, p. 44) ['a landscape of tents, wooden shacks and tarps: white, blue and green' (Erpenbeck 2017, chp. 8)]. He sits down and observes the interactions of the black refugees and their white supporters for two and a half hours without talking to them (Erpenbeck 2015, pp. 44-50). After his visit to Oranienplatz, his research project begins in earnest, "[d]ie nächsten zwei Wochen verwendet Richard darauf, einige Bücher zum Thema zu lesen und einen Fragenkatalog für die Gespräche, die er mit den Flüchtlingen führen will, zu entwerfen" (Erpenbeck 2015, p. 51) ['Richard spends the next two weeks reading several books on the subject of the refugees and drawing up a catalog of questions for the conversations he wants to have with them' (Erpenbeck 2017, chp. 9)]. The next time he visits Oranienplatz, he arrives just in time "um zu sehen, wie auf dem abgesperten und von Polizei umstellten Platz die letzten Bretter, Planen, Matratzen und Pappen von einem Bagger zusammengeschoben, auf LKWs verladen und fortgeschafft wurden" (Erpenbeck 2015, p. 54) ['to see the last of the boards, tarps, mattresses, and cardboard signs being shoved into a heap by a bulldozer, loaded onto trucks and carted away' (Erpenbeck 2017, chp. 10)].

\section{The Refugees' Stories}

It is only now, after the asylum seekers have left the Oranienplatz and have been moved to other housing, that Richard actually speaks to them. Using his painstakingly constructed questionnaire, he interviews them individually, but also gradually forms relationships that go beyond his research project, letting one play his piano, giving another odd jobs around the house, and purchasing a property in Ghana for the family of a third (Erpenbeck 2015, p. 282). Richard delves into the details of

3 As Imogen Tyler and Katarzyna Marciniak note, the paradox of such protests is that although they "are 'acts' against the exclusionary technologies of citizenship, which aim to make visible the violence of citizenship as regimes of control," "protestors are compelled to make their demands in the idiom of the regime of citizenship they are contesting" in order to effect material change (Marciniak and Tyler 2013, p. 146) 
the refugees' places of origin, their lives, their suffering and the histories of their countries of origin, going back to ancient times. Many of the refugees' stories, as conveyed to Richard, are told in detail, some of them filling whole chapters. The stories uncovered are varied and horrendous: Raschid, for instance, was saved from a shipwreck in which 550 of the 800 asylum seekers on the boat, including his own children, drowned (Erpenbeck 2015, pp. 61-62, 240). This followed fleeing Nigeria as a child when his father was burnt alive in his own car (Erpenbeck 2015, p. 112). Another refugee, whom Richard dubs Apoll, is a Tuareg orphan and former child slave, covered in scars from the beatings of his so-called family (Erpenbeck 2015, pp. 67-68). Many of the protesters recall seeing how their friends and families were slaughtered before they fled. As will gradually become clear towards the end of the novel—or may be clear to those familiar with refugee politics from the beginning-most of the Oranienplatz protesters will not be recognized as refugees despite the persecution they have suffered, due to the vagaries and specificities of both German refugee law and international treaties relating to asylum seekers.

The narratives of the refugees' lives are punctuated by the links Richard makes to other similar experiences in his life, in recent history, and in literature. As the novel progresses and the refugees become his friends and acquaintances, these connections gradually move from references to the ancient and medieval literary canon to allusions that are more contemporary or more personal. The refugees' experiences remind the emeritus professor, of various episodes including his mother's flight from Silesia with him as a baby (Erpenbeck 2015, pp. 25-26); his father's role as a soldier in World War II; and his mother's time as a Trümmerfrau ${ }^{4}$ (Erpenbeck 2015, pp. 118-19). Ghanaian Awad's mother died in childbirth, which is reminiscent of Blanchefleur dying when Tristan was born, while Awad's flight from the war in Libya, where he later lived with his father, leads Richard to think of both the long history of German wars encapsulated in the children's song "Maikäfer flieg, mein Vater ist im Krieg" (Erpenbeck 2015, p. 82) ['Cockchafer Fly! Your father's off at war!' (Erpenbeck 2017, chp. 14)], and of the exile of Goethe's Iphigenia to Tauris (Erpenbeck 2015, pp. 82-83). Later, Apoll's decision to ration his consumption of couscous-consuming only a quarter of a modest plate per day-to ensure that he will not become as helpless as a newborn baby so that he can cope if he is deprived of food and water again, reminds Richard of a TV documentary in which a Jewish girl decides to prepare herself for the Polish camps by wearing light shoes in midwinter before deportation (Erpenbeck 2015, pp. 218-19). Another refugee's explanation that he and his best friend decided to split up and find their own way once they arrived in Europe, thinking "vielleicht hat wenigstens einer von uns Glück und kann dann später dem anderen helfen" (Erpenbeck 2015, p. 221) ['one of us might get lucky and then that person could help the other one' (Erpenbeck 2017, chp. 38)], leads Richard to a more general association of the fate of the refugees' with that of the German people historically: "[e]s ist noch nicht so lange her [ ... ] da war die Geschichte der Auswanderung und der Suche nach Glück eine deutsche Geschichte" (Erpenbeck 2015, p. 222) ['Not so long ago [ ... ] the story of going abroad to find one's fortune was a German one' (Erpenbeck 2017, chp. 38)].

Spiegel reviewer Dana Buchzik rejected these allusions, emphasizing the incommensurability of flight:

Auch Blanscheflur starb bei Tristans Geburt, konstatiert der emeritierte Professor, als ein verwaister Flüchtling ihm seine Geschichte erzählt. Auch Mozarts Tamino wurde geprüft und davon abgehalten, weiterzugehen, sinniert Richard, auch Goethes Iphigenie war letztlich Emigrantin auf Tauris—auf den Gedanken, dass zwischen Emigration und Flucht ein Unterschied bestehen könnte, kommt Erpenbecks Protagonist nicht. ${ }^{5}$

4 Trümmerfrauen - literally 'rubble women' — were women who cleared the rubble from bombed German cities after World War II.

5 Stefan Hermes supports her interpretation, focusing on the connections Richard makes between the traumatic experiences of the asylum seekers and those of characters in the European literary canon, and deeming them "denkbar unangemessen, ja zum Teil beinahe lächerlich" ['conceivably inappropriate, and in some instances even ludicrous'] (Hermes 2016). Both Buchzik 
'The emeritus professor notes that Blanchefleur also died during Tristan's birth, when an orphaned refugee tells him his story. Mozart's Tamino was also put to the test, and hindered from venturing further, Richard ruminates, Goethe's Iphigenia was also an emigrant on the peninsula of Tauris-it does not occur to Erpenbeck's protagonist that there could be a difference between emigration and flight.' (Buchzik 2015).

This critique suggests that Erpenbeck's emphasis on the universality of the suffering the refugees have experienced, and are experiencing, flattens difference. It is undeniable that Erpenbeck emphasizes commonalities, yet the stories of the refugees told in Gehen, ging, gegangen are also stories of the particular, featuring the specific experiences of asylum seekers from a diverse range of cultural and religious backgrounds and going beyond the mass concept of the 'refugee', which as Said notes, suggests "large herds of innocent and bewildered people requiring urgent international assistance" (Said 2002, p. 181).

\section{Empathy}

Instead of eliding difference, Erpenbeck is, it seems, trying to trigger the reader's empathy towards asylum seekers, ${ }^{6}$ at a time of increasing concern about Germany's acceptance of refugees and of rising xenophobia. ${ }^{7}$ Assmann and Ines Detmers argue in their introduction to their edited volume Empathy and its Limits that "empathy is a new topic," pointing out both that it is a recent topic in a number of disciplines, and also that there has been very little interaction between different disciplines' approaches to it (Assmann and Detmers 2016, p. 1). Yet, literature has long been regarded as playing an important role in the development of empathy. ${ }^{8}$ Susan Sontag, for instance, argues that the "ability to weep for those who are not us or ours" is exactly what literary narratives can "train" (Sontag 2007, p. 205), while Martha Nussbaum contends that the genre of the novel in particular, "on account of some general features of its structure, generally constructs empathy and compassion in ways highly relevant to citizenship" (Nussbaum 1995, p. 10).

Furthermore, as Stef Craps notes, the concept of empathy "plays a crucial role in much recent work on trauma and witnessing" (Craps 2008, p. 191). Empathy is, for instance, central to Alison Landsberg's theory of 'prosthetic memory', which was first developed in relation to mass media events but which has proven useful in reference to literature too. She defines prosthetic memories as "privately felt public memories that develop after an encounter with a mass cultural representation of the past, when new images and ideas come into contact with a person's own archive of experience" (Landsberg 2004, p. 19). Landsberg argues that "even memories of events that one did not live through can be affectively charged and therefore have the potential to produce empathy and to alter an individual's political commitments" (Landsberg 2015, p. 149). She explains further that "empathy is about developing compassion not for our family or friends or community, but for others-others

and Hermes focus on the parallels drawn to the literary canon, not mentioning those drawn to Richard's personal history and German collective history.

6 Some reviewers commented on this point, Jörg Magenau, for instance wrote: "Die didaktische Absicht [ ... ] ist klar: der anonymen Menge der Flüchtlinge persönliche Gesichter und Geschichten zu verleihen, um so die Empathie zu steigern" ['The didactic intention [ ... ] is clear: to lend the anonymous refugee masses personal faces and stories, and thus to increase empathy'] (Magenau 2015). Friedmar Apel, on the other hand, disagreed: "Obwohl diese Geschichten sehr bewegend sind, appelliert 'Gehen, ging, gegangen' nicht vordergründig an das Mitleid des Lesers" ['Although these stories are very moving, "Gehen, ging, gegangen" does not ostensibly appeal to the compassion of the reader'] (Apel 2015).

7 In a recent telephone survey, 65\% of Germans reported that they felt less safe than 2 years ago (Stockrahm 2017); at the same time xenophobic attacks on foreigners have risen (Die Zeit 2016), with more than 3500 attacks in 2016 (Der Spiegel 2017). Political scientist Robert Vehrkamp makes a clear connection between the arrival of refugees and support for the right-wing populist AfD (Alternative for Germany) party, arguing that the rise in AfD support in 2015 was related to the refugee crisis, and that the fall in their poll numbers in early 2017 was the result of the fact that the refugee crisis was no longer the dominant theme in German politics (Fieber 2017).

8 As has theatre, which is why Brecht famously used Verfremdungseffekte (alienation effects) to avoid awakening empathy in his audience. Jill Bennett relates Dominick LaCapra's notion of empathic unsettlement, discussed below, to Bertolt Brecht's critique of crude empathy (Bennett 2005, p. 10). 
who have no relation to us, who resemble us not at all, whose circumstances lie far outside of our own experiences" (Landsberg 2009, p. 223). Dominick LaCapra also makes the link between empathy and the remembrance of traumatic events, emphasizing the importance of empathy for writing about traumatic historical events. He argues that historians (and fiction writers) should approach traumatic historical experiences with "empathic unsettlement," which avoids both the pitfalls of numbing and of "unchecked identification, vicarious experience and surrogate victimage" (LaCapra 2001, p. 40). According to LaCapra, "[e]mpathy in this sense is a form of virtual, not vicarious, experience, related to what Kaja Silverman has termed heteropathic identification, in which emotional response comes with respect for the other and the realization that the experience of the other is not one's own" (LaCapra 2001, p. 40; Silverman 1996). Although Buchzik's review of Gehen, ging, gegangen suggests that in her opinion Erpenbeck, or at least her narrator Richard, has fallen into the trap of 'unchecked identification' identified by LaCapra, a clear distinction is always made between the experiences of the individual refugees, on the one hand, and Richard and the other Western figures-fictional or otherwise - to whom their experiences are linked, on the other. ${ }^{9}$

Amos Goldberg argues, drawing on Hannah Arendt's work on the refugee and the modern nation state after World War II, that "empathy towards the refugee presents such a great challenge and is so unsettling, since it is directed at the traumatic element within the modern nation state" (Goldberg 2016, p. 71). In this understanding the refugee represents the 'other' of the modern nation state, thus challenging and undermining it. Although theoretical writings on empathy in both literary and trauma theory underline the importance of difference being acknowledged for empathy to be felt (as opposed to sympathy, which is based on similarity), they largely focus on empathy being felt by those in the West towards Western literary figures or historical victims of trauma. Yet most of the asylum seekers arriving in Germany in recent times, such as the group of protesters portrayed in Gehen, ging, gegangen who stem from Africa and the Middle East, are not from the West. As Judith Butler notes, those in the West are less likely to feel empathy for non-Westerners, as signified by the way in which the loss of different kinds of lives are treated. Butler argues that while some lives are publically acknowledged and grieved, other lives (for instance AIDS deaths or the large numbers of people dying in Africa) are "unmarkable" and "ungrievable" (Butler 2004, p. 35). Butler contends that the narratives in the Western media "stage the scene and provide the narrative means by which 'the human' in its grievability is established" (Butler 2004, p. 38). Susannah Radstone makes a similar argument in relation to trauma theory, noting that while certain events are labeled traumatic, others "quite patently" are not (Radstone 2007, p. 25). Moreover, she argues, "it is the sufferings of those categorized, in the West as 'other', that tend not to be addressed via trauma theory-which becomes in this regard, a theory that supports politicized constructions of those with whom identifications via traumatic sufferings can be forged and those from whom such identifications are withheld" (Radstone 2007, p. 25).

By emphasizing the similarities between the individual traumatic experiences of the Oranienplatz protesters (before, during and after their flight to Germany) and the traumatic experiences of a range of people-fictional and other-whose lives most Germans would regard as valued, Erpenbeck attempts to establish empathy and shift these lives from ungrievable to grievable in Butler's terms. The narratives of refugees' suffering recounted by Erpenbeck have a "humanizing effect," producing "an intense identification by arousing feelings of fear and sorrow," much like the stories told in the media about the final moments of those who died in the World Trade Center, as discussed by Butler (Butler 2004, p. 38).

In the context of the current German refugee crisis, the philosopher Hilge Landweer confirmed the importance of drawing parallels to recognizable experiences for empathy to be felt, and emphasized

9 Indeed, Hermes criticizes Erpenbeck for writing the traumatic experiences of the refugees in third person, as conveyed to Richard, and not from the first-person perspective of the refugees, yet such a first-person narrative would run the risk of both cultural appropriation and the appropriation of traumatic experiences (Hermes 2016, p. 185). 
that empathy can be cultivated through a decided focus on commonalities and the belief that only luck is responsible for the fact that one is in a better situation (Landweer 2016). The focus on commonalities and similar personal or familial experiences is clear throughout Gehen, ging, gegangen, but Erpenbeck also emphasizes the role of fortune and the possibility that fortunes could be reversed. Noting that postwar posterity in Germany was not a result of the merits of individual Germans, Richard states, "[w]enn es aber nicht ihr eigenes Verdienst war, dass es ihnen so gut ging, war es andererseits auch nicht die Schuld der Flüchtlinge, dass es denen so schlecht ging" (Erpenbeck 2015, p. 120) ['[b]ut if this prosperity couldn't be attributed to their own personal merit, then by the same token the refugees weren't to blame for their reduced circumstances' (Erpenbeck 2017, chp. 19)]. Richard's friend Silvia, whose family also fled from the former Eastern territories, similarly reflects, "[i]ch stelle mir immer vor, dass auch wir noch einmal fliehen müssen, und dann wird uns auch niemand helfen" (Erpenbeck 2015, p. 120) ['I keep imagining that someday it'll be us having to flee, and no one will help us either' (Erpenbeck 2017, chp. 19)]. As all of the elements Landweer outlines work to awaken Richard's empathy for the refugees, it seems that Erpenbeck is simultaneously trying to awaken the same in the reader.

Erpenbeck's decision to make Richard a flawed and fallible individual, who describes the refugees as kohlrabenschwarz ['jet black'] (Erpenbeck 2015, p. 155), lusts after and objectifies the beautiful young woman of Ethiopian background who has volunteered to teach the protesters German (Erpenbeck 2015 , pp. 134, 174), ${ }^{10}$ and reflects over the course of the novel on the ways in which his treatment of his deceased wife was less than ideal, seems intended to make him and his experience of empathy with the asylum seekers identifiable to an imagined (fallible) German public. Indeed, the Frankfurter Rundschau review of Gehen ging gegangen went so far as to label Richard an everyman ('Jedermann') (Von Sternburg 2015), although the reviewer in Die Welt calls him 'kein Jedermann und kein Niemand' ['no everyman and no no-one'] (Lühmann 2015). ${ }^{11}$ Yet, as Hermes notes, Richard's racism and naivety when it comes to matters of both cultural difference and refugee law decrease during the course of the novel as he gets to know the asylum seekers and familiarizes himself with the web of laws and regulations applying to them (Hermes 2016, p. 184).

\section{Postmemory of the Flight from Silesia}

Although Erpenbeck depicts a variety of Richard's personal experiences as leading to his growing empathy with the asylum seekers, including his continuing experience of disorientation and loss in post-reunification Berlin as an East Berliner, I will focus particularly on flight and expulsion. Since the beginning of the refugee crisis, a number of journalists, bloggers and other public commentators have reminded the public of the flight and expulsion of an estimated 12-14 million ethnic Germans from Central and Eastern Europe after World War II (Douglas 2012) (as compared to the arrival of a total of approximately 1.2 million asylum seekers in Germany between 2015 and 2016 (Drach 2017)). Memory of the flight and expulsions was a politically charged issue in Germany from the 1960s onwards, with memory politics divided along political lines. As Andreas Huyssen notes, "[t]he Right spoke of Dresden and the expulsion from the East, the Left spoke of Auschwitz" (Huyssen 2006, p. 184). ${ }^{12}$ It is only in the years since reunification that remembering the expulsions and lost homes in the East has begun to be disentangled from revisionist and revanchist politics. ${ }^{13}$ Most Germans have a personal

10 A classics scholar lusting after a woman of Ethiopian descent has overtones of the colonialism that Richard criticizes elsewhere in the novel, first referring to the German colonization of Namibia (Erpenbeck 2015, p. 53), and later suggesting that the exploitative practices of Western companies in the current day suggest a continuation of colonialism (Erpenbeck 2015, p. 182).

11 Alexandra Ludewig's suggestion that Richard is a 'Bildungsbürger' [member of the educated classes] intended to represent a broad German middle class, is more persuasive (Ludewig 2016, p. 270).

12 The left considered that the loss of the German lands was the price that the Germans had to pay for the atrocities of the Nazi-era, and that mourning this bereavement would only imply they did not understand their historical guilt.

13 At the time of the turn of the millennium, the publication of a number of texts addressing or depicting German suffering during and after World War II-most prominently Jörg Friedrich's history of allied air raids on Germany from 1940-1945 Der Brand [The Fire], W G. Sebald's essay Luftkrieg und Literatur [Air War and Literature], and Günter Grass's novel Im Krebsgang 
connection to the historical experience of flight and expulsion, as noted by Assmann, and this is one of the main reasons that supporters of Merkel's refugee policy have emphasized this history during the migrant crisis, hoping that these memories would help "Ähnlichkeiten zu entdecken und Unterschiede zurückzustellen" ['to discover similarities and to put aside differences'] (Assmann 2016b).

As Assmann notes elsewhere, Marianne's Hirsch term 'postmemory', which describes the transmission of traumatic experiences from one generation to the next, can be applied to the children of those ethnic Germans who fled or were expelled during and after World War II (Assmann 2016a). Hirsch writes:

Postmemory characterizes the experience of those who grow up dominated by narratives that preceded their birth, whose own belated stories are evacuated by the stories of the previous generation shaped by traumatic events that can neither be understood nor recreated. I have developed this notion in relation to children of Holocaust survivors, but I believe it may usefully describe other second-generation memories of cultural or collective traumatic events and experiences (Hirsch 1997, p. 22).

Postmemory is not memory, "but at the same time, it approximates memory in its affective force" (Hirsch 2008, p. 109). Hirsch's concept of postmemory bears some relation to Landsberg's notion of prosthetic memory, which was developed more recently and was briefly discussed above, as both refer to the transmission of traumatic memories to someone who has never personally experienced the traumatic experience, but while Hirsch focuses on the transmission between family members over a long period of time, Landsberg envisions memories of traumatic events being transferred in contexts where there is no personal connection to the victims of those traumatic events. ${ }^{14}$ The extent to which the narrative of Richard's mother's traumatic experiences dominated his childhood, and ingrained themselves in his memory, becomes clear in the following passage:

Er selbst war bei der Übersiedlung seiner Familie von Schlesien nach Deutschland noch ein Säugling gewesen und wäre im Tumult der Abreise beinahe von seiner Mutter getrennt worden, hätte ihn nicht auf dem überfüllten Bahnsteig ein russischer Soldat seiner Mutter über die Köpfe vieler anderer Aussiedler hinweg noch ins Zugabteil hineingereicht. Diese Geschichte war ihm von seiner Mutter so oft erzählt worden, dass er sie beinahe für seine eigene Erinnerung hielt (Erpenbeck 2015, pp. 25-26).

[He himself had been an infant when his family left Silesia and resettled in Germany. In the tumult of the departure, he almost got separated from his mother; he would have been left behind outright if it hadn't been for a Russian soldier, who, amid the press of the people on the station platform, handed him to his mother through the train's window over the head of many other resettlers.] (Erpenbeck 2017, chp. 3).

The traumatic transmitted memory of nearly being permanently separated from his mother has become almost indistinguishable from his own memory. This accords with Hirsch's description of postmemory as "the relationship of the second generation to powerful, often traumatic, experiences that preceded their births but were nevertheless transmitted to them so deeply as to constitute memories

[Crabwalk] - were widely hailed as signs that a taboo on German suffering in public discourse and literature had been lifted. While, as a number of commentators have since noted, it is inaccurate to speak of a previous blanket taboo on German suffering, including flight and expulsion, the topic has since become much more widespread in German literature and public discourse and is no longer so tainted by association with right wing political groups (Stone 2016, pp. 19-20).

14 Hirsch's concept of postmemory is also similar to LaCapra's notion of 'empathic unsettlement' discussed above, although the two theorists focus on different forms of the transmission of traumatic memory. Like LaCapra (LaCapra 2001, p. 40), Hirsch makes use of Kaja Silverman's concept of 'heteropathic identification' to posit a form of empathic connection that does not involve over-identification with, or appropriation of, the victim's experience (Hirsch 1997, p. 83). As Katherine Stone notes, "[t]he desire to bridge the gap between self and other, without unreflectively appropriating the latter's experiences, is for Hirsch a driving force of the work of postmemory" (Stone 2016, p. 475). 
in their own rights" [emphasis added] (Hirsch 2008, p. 103). Richard's transferred memory deviates slightly from this description as he did experience the event directly, but at such a young age that it is extremely unlikely he would actually remember it. Elsewhere in the novel, Richard wonders whether his visceral reaction to the sound of a fire alarm siren at the refugee hostel is grounded in his own memory or transmitted memory: "Richards Mutter hat mit ihm, er war noch ein Säugling, in einem Berliner Bombenkeller gesessen. Ob Richard sich an die Angst des Säuglings, der er war, oder an die Angst seiner Mutter erinnert? [ . . ] Erinnert ein Säugling sich an den Krieg?" (Erpenbeck 2015, pp. 214-15) ['Richard's mother had sat with him in a Berlin bomb cellar when he was just an infant. Can Richard remember the fear he felt as an infant, or his mother's fear? Can an infant remember a war? (Erpenbeck 2017, chp. 36)]. This postmemory also reminds him of the similarly traumatic memory of one of the refugees: "Tristan hat gesagt: Wir saßen in den Baracken, als die europäischen Bomben auf Tripoli fielen, und hatten Angst, dass eine davon uns trifft' (Erpenbeck 2015, p. 214) ['Tristan said once: We were sitting in the barracks when the European bombs fell over Tripoli and we were afraid one of them would hit us' (Erpenbeck 2017, chp. 36)]. A prosthetic memory has been formed, combining Tristan's narration of wartime Tripoli with Richard's “own archive of experience" (Landsberg 2004, p. 19). On the basis of his own postmemory and his prosthetic memory of wartime Tripoli, Richard can thus understand why one of the refugees, Yaya, cuts the wire for the siren, ending the "mörderisch lauten Alarmton" ['murderously loud alarm'], which is a form of "Folter" ['torture'], although he is not aware of the specific traumatic memory that leads Yaya to do so (Erpenbeck 2015, p. 214).

\section{Conclusions}

Both Assmann and Erpenbeck point out that the lack of empathy encapsulated in the xenophobia towards asylum seekers and other migrants in present-day Germany also has a precedent in the xenophobia encountered by the ethnic Germans arriving in postwar Germany from Central and Eastern Europe. Assmann notes the shocking parallels between xenophobia now and after World War II, when locals strengthened their sense of cohesion by discriminating against the refugees and the refugees encountered ridicule, abuse, and hateful slogans, some of which went so far as to suggest the refugees be sent to Auschwitz (Assmann 2016a). Richard is reminded by the rhyming slogan of an unnamed East German political party "Lieber Geld für die Oma-als für Sinti und Roma" ['Let's save our cash for Granny — not the Roma and Sinti'] and of Brecht's poem about a horse being eaten alive in post-World War I Berlin and worrying about the emotional calcification of its killers as it is being chopped apart (Erpenbeck 2015, p. 207; Erpenbeck 2017, chp. 34) ${ }^{15}$. Richard asks, "[a]ber welchen Krieg hatten die Menschen jetzt hinter sich?" (Erpenbeck 2015, p. 207) ['[b]ut what war have people now just been through?' (Erpenbeck 2017, chp. 34)], suggesting that there may have been understandable barriers to empathy in the deprivations of the immediate aftermath of World War I, but that these no longer exist.

Elsewhere in the novel, Richard also muses retrospectively that the tents on Oranienplatz were at risk of being set alight, implicitly alluding to the many arson attacks that have been made and continue to be made on refugee housing in Germany, especially in the East. He concludes: "[d]ie Afrikaner wussten bestimmt überhaupt nicht, wer Hitler war, aber dennoch: Nur wenn sie Deutschland jetzt überlebten, hatte Hitler den Krieg wirklich verloren (Erpenbeck 2015, p. 64) [‘[t]he Africans probably had no idea who Hitler was, but even so: only if they survived Germany now would Hitler have lost the war' (Erpenbeck 2017, chp. 13)]. As Tyler notes, "[w]hile xenophobic discourses depict the asylum-seeker as a dehumanized, undifferentiated foreign mass, hoard [sic], influx, etc., humanitarian discourses ask the public to recognize 'the human face' of specific asylum-seekers" (Tyler 2006, p. 194). By telling the stories of the asylum seekers who occupied the Oranienplatz, Erpenbeck counters xenophobic

15 Xenophobic attacks continue to be more common in the former GDR than elsewhere in Germany (Eckert 2017). 
discourse and attempts to reposition the asylum seekers "as subjects who matter 'like us'" (Tyler 2006, p. 194), and bring them "under the rubric of the 'human'" (Butler 2004, p. 46).

Writing about the politics of literature, Jacques Ranciére explains that political activity "makes visible what was invisible, it makes audible as speaking beings those who were previously heard only as noisy animals" (Rancière 2011, p. 4), in other words the political work of literature is to expand points of emphatic connection. ${ }^{16}$ Indeed, Ranciére's theory of politics as acts of becoming visible seems to be reflected in one of the slogans of the Oranienplatz protest mentioned a number of times in Gehen, ging, gegangen, "we become visible."17 In the novel, based on the interviews Erpenbeck herself held with the occupiers of Oranienplatz, ${ }^{18}$ the lives of some members of the anonymous multitudes seeking refuge in Germany do become visible, do become grievable. By situating the current refugee crisis in the context of literary and historical experiences of displacement, and by focusing on individual stories of suffering, Erpenbeck overtly, but also successfully, appeals to the empathy of the reader. She reminds the reader of the commonalities of the traumatic experiences of the asylum seekers with the postwar flight and expulsion of ethnic Germans from Eastern Europe, a memory that many Germans share as either postmemory or prosthetic memory, and thus suggests, like Assmann, that "unsere heutige Erfahrung der Migration verlangt nach einer längeren Perspektive, in der wir Zusammenhänge entdecken und Parallelen herstellen können" ['our current experience of migration demands a longer perspective, in which we can discover coherencies and establish parallels'] (Assmann 2016a).

Conflicts of Interest: The author declares no conflict of interest.

\section{References}

Agamben, Giorgio. 1998. Homo Sacer. Sovereign Power and Bare Life. Translated by Daniel Heller-Roazen. Stanford: Stanford University Press.

Apel, Friedmar. 2015. Wir wurden, werden, sind sichtbar. Die Frankfurter Allgemeine Zeitung, September 16.

Assmann, Aleida. 2016a. Erinnerung an Flucht und Vertreibung nach dem Zweiten Weltkrieg. Available online: https:/ / www.boell.de/de/2016/06/22/erinnerung-flucht-und-vertreibung-nach-dem-zweitenweltkrieg (accessed on 29 May 2017).

Assmann, Aleida. 2016b. Hat Deutschland im Rahmen der Flüchtlingskrise eine besondere historisch bedingte Verantwortung? Philosophie Magazin, 48.

Assmann, Aleida, and Ines Detmers. 2016. Empathy and Its Limits. London: Palgrave Macmillan UK.

Bartels, Gerrits. 2015. Jenny Erpenbeck im Interview: ‘Hinter der Ordnung verbirgt sich Angst.'. Der Tagesspiegel, October 12.

Bennett, Jill. 2005. Empathic Vision: Affect, Trauma, and Contemporary Art. Stanford: Stanford University Press.

Bhimji, Fazila. 2016. Visibilities and the Politics of Space: Refugee Activism in Berlin. Journal of Immigrant and Refugee Studies, 1-19. [CrossRef]

Buchzik, Dana. 2015. Trifft ein Berliner Professor auf Flüchtlinge. Der Spiegel, September 2.

Butler, Judith. 2004. Precarious Life: The Powers of Mourning and Violence. New York: Verso.

Craps, Stef. 2008. Linking Legacies of Loss: Traumatic Histories and Cross-Cultural Empathy in Caryl Phillips's Higher Ground and The Nature of Blood. Studies in the Novel 40: 191-202. [CrossRef]

Der Spiegel. 2017. Mehr als 3500 Angriffe auf Flüchtlinge. Der Spiegel, February 26.

Die Zeit. 2016. Zahl fremdenfeindlicher Attacken verdoppelt sich. Die Zeit, September 24.

Douglas, Ray M. 2012. Orderly and Humane: The Expulsion of the Germans after the Second World War. New Haven: Yale University Press.

16 Both Landsberg and LaCapra also emphasize the potential for empathy to lead to social critique and political action (Landsberg 2004, p. 21; LaCapra 2001, p. 219).

17 See also (Wilcke and Lambert 2015), which discusses the protests using Ranciére as a framework, but does not mention this slogan, cited by a number of news sources before the publication of the novel.

18 In her acknowledgments Erpenbeck thanks thirteen males for "viele gute Gespräche" ('many good conversations') and also provides the account details for a charity that helps refugees in Berlin (Erpenbeck 2015, pp. 350-51). 
Drach, Markus C. Schulte von. 2017. Zahl der Flüchtlinge in Deutschland extrem gesunken. Süddeutsche Zeitung, January 11.

Eagleton, Terry. 1970. Exiles and Émigrés: Studies in Modern Literature. London: Chatto \& Windus.

Eckert, Daniel. 2017. Fremdenfeindlichkeit macht Ostdeutschland zum Risiko-Standort. Die Welt, March 17.

Erpenbeck, Jenny. 2015. Gehen, ging, gegangen. Munich: Knaus.

Erpenbeck, Jenny. 2017. Go, Went, Gone, Kindle ed. Translated by Susan Bernofsky. New York: New Directions.

Fadaee, Simin. 2015. The Immigrant Rights Struggle, and the Paradoxes of Radical Activism in Europe. Social Movement Studies: Journal of Social, Cultural and Political Protest 14: 733-39. [CrossRef]

Fieber, Marco. 2017. Die AfD sieht sich im Aufwind-Doch die Zahlen zeigen: Die Partei könnte an der 5-Prozent Hürde scheitern. Huffington Post Germany, April 28.

Gehrke, Christian. 2017. Gerhart-Hauptmann-Schule: Das kostet das Flüchtlingshaus wirklich. Berliner Kurier, May 22.

Goldberg, Amos. 2016. Empathy, Ethics, and Politics in Holocaust Historiography. In Empathy and Its Limits. Edited by Aleida Assmann and Ines Detmers. London: Palgrave Macmillan UK, pp. 52-76.

Hermes, Stefan. 2016. Grenzen der Repräsentation: Zur Inszenierung afrikanisch-europäischer Begegnungen in Jenny Erpenbecks Roman Gehen, ging, gegangen. Acta Germanica: German Studies in Africa 44: 171-91.

Hirsch, Marianne. 1997. Family Frames: Photography, Narrative, and Postmemory. Cambridge: Harvard University Press.

Hirsch, Marianne. 2008. The Generation of Postmemory. Poetics Today 29: 103-28. [CrossRef]

Huyssen, Andreas. 2006. Air War Legacies: From Dresden to Baghdad. In Germans as Victims: Remembering the Past in Contemporary Germany. Edited by Bill Niven. Basingstoke: Palgrave Macmillan, pp. 181-93.

LaCapra, Dominick. 2001. Writing History, Writing Trauma. Baltimore: Johns Hopkins University Press.

Landry, Olivia. 2015. “Wir sind alle Oranienplatz"! Space for Refugees and Social Justice in Berlin. Seminar: A Journal of Germanic Studies 51: 398-413. [CrossRef]

Landsberg, Alison. 2004. Prosthetic Memory: The Transformation of American Remembrance in the Age of Mass Culture. New York: Columbia University Press.

Landsberg, Alison. 2009. Memory, Empathy, and the Politics of Identification. International Journal of Politics, Culture, and Society 22: 221-29. [CrossRef]

Landsberg, Alison. 2015. Engaging the Past: Mass Culture and the Production of Historical Knowledge. New York: Columbia University Press.

Landweer, Hilge. 2016. Was sind die entscheidenden Faktoren dafür, dass wir Empathie mit Flüchtlingen empfinden? Philosophie Magazin, 47.

Ludewig, Alexandra. 2016. Jenny Erpenbecks Roman Gehen, Ging, Gegangen (2015). Eine zeitlose Odyssee und eine zeitspezifische Begebenheit. In Niemandsbuchten und Schutzbefohlene: Flucht-Räume und Flüchtlingsfiguren in der Deutschsprachigen Gegenwartsliteratur. Edited by Johannes Kleine and Charlton Payne Thomas Hardtke. Göttingen: V \& R unipress, pp. 269-85.

Lühmann, Hannah. 2015. Ein Roman als Crashkurs in Flüchtlingskunde. Die Welt, August 31.

Magenau, Jörg. 2015. Ein Stückchen Acker in Ghana. Die Süddeutsche Zeitung, August 30.

Marciniak, Katarzyna, and Imogen Tyler. 2013. Immigrant Protest: An Introduction. Citizenship Studies 17: 143-56.

Nussbaum, Martha. 1995. Poetic Justice: The Literary Imagination and Public Life. Boston: Beacon.

Radstone, Susanna. 2007. Trauma Theory: Contexts, Politics, Ethics. Paragraph 30: 9-29. [CrossRef]

Rancière, Jacques. 2011. The Politics of Literature. Cambridge: Polity.

Said, Edward. 2002. Reflections on Exile and Other Essays. Cambridge: Harvard University Press.

Silverman, Kaja. 1996. The Threshold of the Visible World. New York: Routledge.

Sontag, Susan. 2007. Literature is Freedom. In At the Same Time: Essays and Speeches. Edited by Paolo Dilonardo and Anne Jump. New York: Farrar, Straus \& Giroux, pp. 192-209.

Stockrahm, Sven. 2017. Je fremder, desto schlimmer unsere Fantasien. Die Zeit, February 8.

Stone, Brangwen. 2016. Heimkehr? Narratives of Return to Germany's Former Eastern Territories 1965-2001. Hannover: Wehrhahn Verlag.

Stone, Katherine. 2016. Sympathy, Empathy, and Postmemory: Problematic Positions in Unsere Mütter, Unsere Väter. Modern Humanities Research Association 111: 454-77.

Tyler, Imogen. 2006. "Welcome to Britain": The Cultural Politics of Asylum. European Journal of Cultural Studies 9: 185-202. [CrossRef] 
UNHCR. 2017. UNHCR-Bericht: Flucht und Vertreibung erreichen 2016 neuen Höchstand. Available online: http:/ / www.unhcr.org/dach/de/15212-globaltrends2016.html (accessed on 4 June 2017).

Von Sternburg, Judith. 2015. Jedermann und die Afrikaner. Frankfurter Rundschau, September 1.

Wiedemann, Caroline. 2015. Was wurde aus den Aktivisten vom Oranienplatz? Der Spiegel, April 22.

Wilcke, Holger, and Laura Lambert. 2015. Die Politik des O-Platzes. (Un)Sichtbare Kämpfe einer Geflüchteten Bewegung. Movements: Journal für kritische Migrations-und Grenzregimeforschung, vol. 1. Available online: http:/ / movements-journal.org/issues/02.kaempfe/06.wilcke,lambert--oplatz-k\%C3\%A4mpfegefl\%C3\%BCchtete-bewegung.html (accessed on 22 July 2017).

2017 by the author. Licensee MDPI, Basel, Switzerland. This article is an open access article distributed under the terms and conditions of the Creative Commons Attribution (CC BY) license (http://creativecommons.org/licenses/by/4.0/). 